\title{
HEPATITIS C VIRUS AND HEPATITIS C-INFECTION
}

Luis Jesuino de Oliveira Andrade*, Paulo Roberto Santana de Melo*, Isabel Cristina Pithon Lins*, Raymudo Paraná*, Augusto Cesar Ferreira Lins*

* Faculdade de Medicina - Universidade Estadual de Santa Cruz - UESC - Bahia. E-mails: luis_jesuino@yahoo.com.br; pmelo11@yahoo.com.br; isabelpithon@yahoo.com.br; unif@svn.com.br; aflins@yahoo.com.br

\begin{abstract}
Hepatitis $\mathrm{C}$ virus (HCV) belongs to the Hepacivirus genus, Flaviviridae family, has six major genotypes and more than 70 subtypes. HCV has a major impact on public health, because it infects around $3 \%$ worldwide population, with an estimated global incidence of three to four million new infections per year. HCV infection was first suspected in the 1970s, when this new type of hepatitis transmitted by blood was then called "non-A, non-B" hepatitis. HCV is an enveloped, positive-stranded RNA virus, and its genome was identified in 1989. It's transmitted primarily via the blood route through of injection drug use, sharing syringes, and blood transfusion. Anti-HCV antibody and HCV RNA testing are used to diagnose acute and chronic hepatitis $\mathrm{C}$, and HCV genotype should be systematically determined for indication and duration of treatment. After acute infection, 15\%-25\% of persons appear to resolve their infection without sequelae, whereas $75 \%-85 \%$ evolve to chronicity, which may exhibit various complications with the evolution of the infection. The standard treatment for chronic infection with $\mathrm{HCV}$ in the last decade has been the combination therapy of pegylated interferon alpha plus ribavirin. However, this therapy is associated with significant adverse effects, but recent developments of new drugs' combinations are changing the treatment paradigm in HCV infection. In this article, we review the information on HCV, how the HCV biology, diagnosis, management, preventive modalities, and therapeutics.
\end{abstract}

Keywords: Hepatitis C virus; Hepatitis C. Diagnosis; Prevention; Treatment.

\section{INTRODUCTION}

Hepatitis C virus (HCV) belongs to the Hepacivirus genus, Flaviviridae family, has six major genotypes, more than 70 subtypes. HCV has a major impact on public health because it infects around 3\% worldwide population, and more than 350.000 people die from HCV-related liver diseases every year. ${ }^{(1,2)}$ HCV infection was first suspected in the 1970s, when this new type of hepatitis transmitted by blood was then called "non-A, non-B" hepatitis. HCV is an enveloped, positive-stranded RNA virus, and its genome was identified in 1989.(3) The major routes of 
transmission of HCV are injection drug use, blood transfusion, and sharing syringes. Transmission can also occur by healthcare related procedures, tattooing, vertical transmission, and sexual transmission, but are less frequent as compared to transmission initially cited. Anti-HCV antibody and HCV RNA testing are keys to diagnosing correctly acute and chronic hepatitis $C$, and to determine the indication and duration of treatment. (4) Besides hepatocytes, HCV infects different cells.

The The standard treatment for HCV infection with the combination of pegylated interferon alpha (Peg-IFN $\alpha$ ) with ribavirin (RIB) is associated with significant adverse effects. Recent developments of new drugs' combinations are changing the treatment paradigm. ${ }^{(5)}$ In this article, we review the information on HCV infection, considering its biology, diagnosis, therapeutics modalities, and prevention.

\section{THE HEPATITIS C VIRUS}

HCV infection was first suspected in the 1970s, when this new type of hepatitis transmitted by blood was then called "non-A, non-B" hepatitis. In 1989, the HCV was first described by Choo et al. from the cloning of nucleic acids, derived from infectious chimpanzee plasma, and screening of clones produced with a human chronic non- $A$, non- $B$ hepatitis serum. ${ }^{(3)} \mathrm{HCV}$ is shown to be responsible for most cases of post-transfusion hepatitis and it is a major cause of liver disease worldwide with potential morbidity. After cloning in 1989 described by Choo, (3) knowledge of clinical and virological aspects of HCV has grown substantially.

\section{HCV BIOLOGY}

$\mathrm{HCV}$ is a hepatotropic RNA virus, enveloped, positive-stranded RNA virus that belongs to the genus of Hepacivirus in the Flaviviridae family, along with Pestiviruses and Flaviviruses. ${ }^{(2)}$ The $\mathrm{HCV}$ has $50-80 \mathrm{~nm}$ in diameter, with a genome of positive-sense, single-stranded linear RNA with approximately 9600 nucleotides, containing a translational large open reading frame that encodes a polypeptide of 3010-3030 amino acid flanked by untranslated regions at both the ends. ${ }^{(6)}$ The HCV genome is divided into two parts: a structural and other non-structural. The precursor is cleaved into at least 10 different proteins named of structural proteins that include the core protein followed by envelope glycosylated proteins: E1, E2, and p7, as well as the nonstructural domain encoding six proteins: $\mathrm{NS}_{2}, \mathrm{NS}_{3}, \mathrm{NS}_{4} \mathrm{~A}, \mathrm{NS}_{4} \mathrm{~B}, \mathrm{NS}_{5} \mathrm{~A}$, and $\mathrm{NS}{ }_{5} \mathrm{~B}$. This genomic structure has a high degree of genetic variability. ${ }^{(7)} \mathrm{HCV}$ is classified into six major genotypes (numbered 1-6) that vary by over $30 \%$ in its nucleotide sequence, and more than 70 subtypes that differ in their nucleotide sequence by $20 \%-25 \% . .^{(8,9)}$ Viral quasispecies of mixed virus populations provides a survival advantage to the virus to create multiple variant genomes and a high rate of generation of variants to allow rapid selection of mutants to new environmental conditions. The genotypes 1, 2 and 3 are globally distributed while others are limited to specific regions of the world. The genotypes $1 a$ and $1 b$ are the most prevalent genotypes in the United States and western of Europe. The genotype 4 is restricted to the Middle East and Central Africa, the genotype 5 is prevalent in South Africa and the genotype 6, in South East Asia. ${ }^{(10)}$ The genotyping is a primary tool for assessing the evolution of infection and determining treatment response and your continuance. ${ }^{(1)}$ A Brazilian nationwide HCV seroprevalence study between in 2005-2009 in the state capitals of the five Brazilian regions showed a weighted prevalence of HCV antibodies in $1.38 \%$. Sero-positivity varied from $0.7 \%$ in the northeastern region to $2.1 \%$ in the northern region. Based on this population-based survey and according to WHO criteria, Brazil can be classified as a country with low HCV endemicity (prevalence below the $2.5 \%$ ). In a population-based study conducted in 1998 in Salvador, the capital of the northeastern State of Bahia, the HCV prevalence was $1.5 \% .^{(12)}$ Several studies in Brazil have reported that HCV genotype 1 is more prevalent than genotype 3 among patients who had received a blood transfusion. ${ }^{(13)}$ The first report on the HCV genotype distribution in Salvador - Bahia in intravenous drug users (IDU's) 
showed a high prevalence in genotype 1, followed by genotype $3 \cdot{ }^{(14)}$

\section{HCV LIFE CYCLE}

Significant advances in understanding the mechanisms of HCV infection have been reported. $\mathrm{HCV}$ infection is a complex process requiring the involvement of viral envelope proteins and multiple host proteins (Figure 1). The entry of the virus into the cell is the first step in viral infection, and replication is a process that involves multiple cell surface molecules in sequential steps. ${ }^{(15)}$ As soon as $\mathrm{HCV}$ crosses the endothelium, the virus potentially concentrates the on the basal surface of the hepatocyte. Posteriorly, the virus internalization occurs by $\mathrm{pH}$ -dependent and clathrin-mediated endocytosis, involving a series of interactions with viral receptors or entry factors such as the scavenger receptor class B type I, CD81, claudin-1, occludin, receptor tyrosine kinases, epidermal growth factor receptor, ephrin receptor $\mathrm{A}_{2}$ and Niemann-Pick $\mathrm{C}_{1}$-like 1 cholesterol absorption receptor. ${ }^{(19,20)}$ The Trojan horse strategy help shields the virus from neutralization. ${ }^{(21)}$ Within hepatocytes, highly sulfated glycosaminoglycans serve as the first attachment sites. While direct E2 binding to sulfated glycosaminoglycans is held, E1 and apolipoprotein $\mathrm{E}$ are also attached to sulfated glycosaminoglycans. Following hepatocyte entry, HCV particle penetrates in acidic endosomal compartment and release its RNA genome into the cytoplasm. The HCV polyprotein is then translated, producing a single polyprotein precursor that is processed, generating 10 individual viral proteins, including core and envelope glycoproteins $E_{1}, E_{2}$, P7, NS2, NS $3, N S_{4} A, N S_{4} B$ and NS 5 A. ${ }^{(19)}$ The HCV release process appears to be closely linked to lipid metabolism because the core association with lipid droplets appears to be critical in viral assembly. ${ }^{(20)}$ The HCV replication is estimated in 10 trillion virion particles produced per day during the active phase of infection. ${ }^{(21)}$

Figura 1 - HCV life cycle.

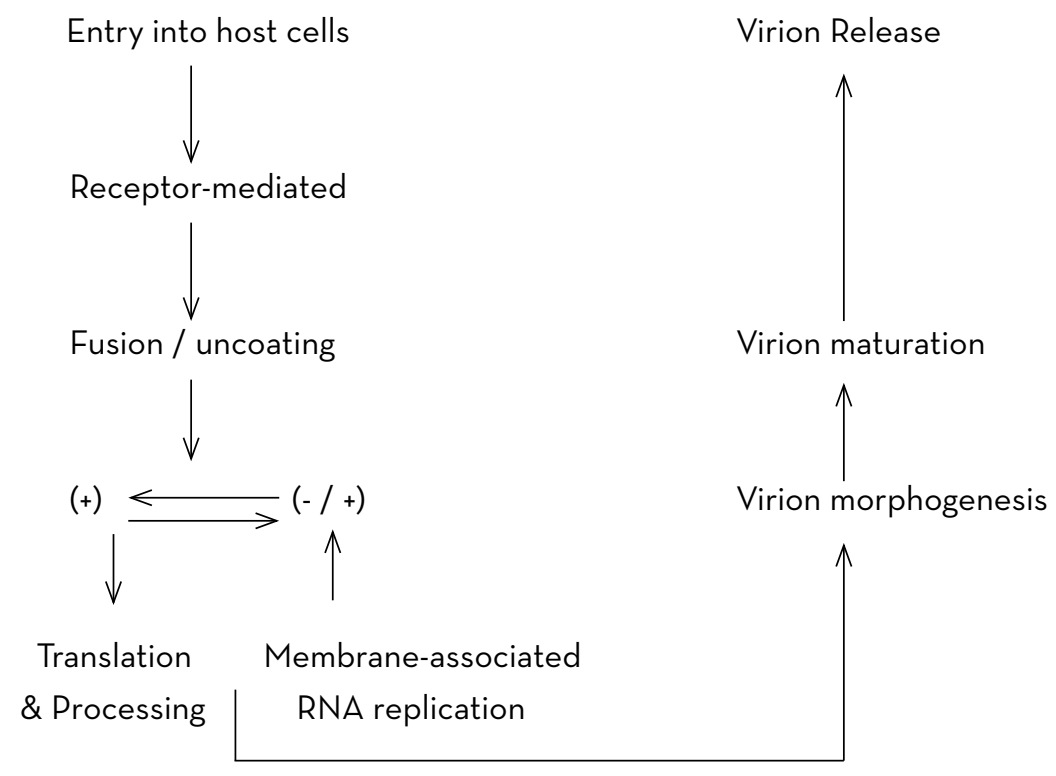

\section{HCV DIAGNOSIS}

Nucleic acid test (NAT) for the detection of HCV RNA is the gold standard for diagnosing active HCV infections; however, novel technologies being developed. Serologic assays and molecular assays are useful because they may detect early infections before clinical signs of disease appear, differentiate acute from chronic infections, and detect persistence of the virus or verify development of 
immunity. There are essentially two approaches to the diagnosis of HCV infection.

\section{SEROLOGY AND VIROLOGY IN HCV}

The serological tests and virological tests have become essential in the diagnose HCV infection, beyond of manage treatment, and evaluate the virological response to antiviral therapy. The serological assays in $\mathrm{HCV}$ include anti-HCV antibody detection, and serological determination of the HCV genotype.

Anti-HCV antibody detection: The "serologic window" between HCV infection and the detection of specific antibodies is variable from individual to individual. The tests are already in the third generation (Table 1).

Table 1 - Generations of immunoassays anti-HCV

\begin{tabular}{cccccccc}
\hline & $\begin{array}{c}\text { DeVeloped } \\
\text { YEAR }\end{array}$ & CORE & E1/E2/NS1 & NS2 & NS3 & NS4 & NS5 \\
\hline $1^{\text {st }}$ generation & 1989 & - & - & - & - & $\begin{array}{c}\text { C10O-3 } \\
\text { (recombinant) }\end{array}$ & - \\
$2^{\text {nd }}$ generation & 1992 & $c 22-3$ & - & - & $c 33 c$ & $c 200$, HC-31 & - \\
$3^{\text {rd }}$ generation & 1993 & $c 22 p$ & - & - & $c 33 c$ & $c 100-3,5-1-1 p$ & NS5 \\
\hline
\end{tabular}

The first-generation test incorporates the c100-3 recombinant epitope from the NS4 region. The incorporation of epitopes c22-3 on HCV core and of $\mathrm{C}_{33} \mathrm{C}$ to $\mathrm{NS}_{3}$ regions, resulted in the secondgeneration test with sensibility of $60 \%$, and the recombinant immunoblot assay II increased its sensitivity to $90 \%$. The third-generation test contains a reconfigured core and $\mathrm{NS}_{3}$ antigens added to an antigen $\mathrm{NS}_{5}$ region, the sensitivity increased by over $99 \% .{ }^{(22)}$ The fourth-generationtest detects, simultaneously, the HCV capsid antigen as well as antibodies to the core, $\mathrm{NS}_{3}, \mathrm{NS}_{4}$, and $\mathrm{NS}_{5}$ regions of the virus, but its use is still limited. ${ }^{23)}$ The detection of anti-HCV antibodies in the blood is based on the use of third-generation enzyme immunoassay, which detect mixtures of antibodies directed against various HCV epitopes, and are used to diagnose acute and chronic hepatitis $C$. The method consists of the capture of circulating anti-HCV antibodies using recombinant antigens, that are demonstrated by anti-antibodies labeled with an enzyme that catalyzes the transformation of a substrate. ${ }^{(24)}$ This technique led to the development of commercially available screening and supplemental assays for anti-HCV immunoglobulin G.
HCV genotyping: Recently, HCV genotyping assays evolved and ultrasensitive quantitative molecular assays were developed. The genotyping is fundamental to determine the therapy type and duration of treatment. ${ }^{(8)}$ The HCV genotyping assay is performed by analyzing banding patterns that are indicative of the genotype. The HCV genotyping is determined by search for antibodies directed to genotype-specific HCV epitopes with a competitive enzyme immunoassay, where two regions of the genome are assessed, the 5' UTR and the core region. Thus, the reference method for $\mathrm{HCV}$ genotyping is genome sequencing of the core/ $\mathrm{E}_{1}$ or the $\mathrm{NS}_{5} \mathrm{~B}$ regions and subsequent phylogenetic analysis. ${ }^{(25,9)}$ Less than $5 \%$ of genotyping feature indeterminate results because of the high genetic variability of HCV. ${ }^{(26)}$

\section{MANAGEMENT OF HCV}

Management of HCV objective is to block disease progression, cirrhosis prevent, reduce the risk of hepatocellular carcinoma, and treat extrahepatic complications. Thence, the management of HCV requires a multidisciplinary approach in health. 
Management of treatment HCV: For several years the standard treatment for chronic infection with HCV was 24 or 48 weeks of therapy with PEG-IFN $\alpha$ and RIB. This changed since direct-acting antiviral agents (DAA) was added to treatment in 2011, increasing the likelihood of sustained virological response (SVR) to $67-75 \%$ in patients without previous treatment infected with genotype 1. ${ }^{(27,28)}$

The treatment remains open, since that PEGIFN $\alpha$, with several side effects, became harder add on a DAA, that can increasing toxicity potential. (29,30) A major obstacle to treatment of HCV, are adverse effects. Almost all patients treated with PEG-IFN $\alpha$ and RIB presents one or more adverse side effects during the course of treatment that includes influenza-like symptoms, neuropsychiatric effects, hematologic abnormalities, and induction of autoimmune disorders. ${ }^{(31)}$ The clinical trials show that, approximately $10-15 \%$ of patients discontinued Peg-IFN $\alpha$ and RIB therapy due to adverse effects. (32) Changes in lifestyle are recommendations in managing chronic hepatitis $\mathrm{C}$ similar to those for obesity, diabetes and metabolic syndrome, confirming the role and injury caused by metabolic factors on the clinical course of HCV infection. Targeted physical activity is a well-understood behavioral modification that decreases metabolic disorders, and the molecular mechanism has been determined to involve exercise-stimulated glucose transport through AMP cyclic. In addition, this change can increase insulin sensitivity in HCV-infected patients, as well as improve early viral response to antiviral therapy and decrease serum $\alpha$-fetoprotein levels. ${ }^{(33)}$ Furthermore, several studies have established a strong link between HCV infection and extrahepatic manifestation, such as rheumatological, endocrine, hematological, dermatological, renal, neurological, autoimmune and systemic manifestations. ${ }^{(34)}$ These data are important for that the physicians offer better management to patients.

\section{HCV TREATMENT}

Protect patients from HCV-related complications and permanent viral eradication is a necessity. The goal of treatment is to eradicate HCV or healing set with SVR, evidenced by undetectable serum HCVRNA 4-24 weeks after the end of treatment.

PEG-IFNa: IFNa was the base of therapy for HCV infection in the 1990s. ${ }^{(35)}$ Posteriorly, the conjugation of polyethylene glycol (PEG) conjugated to IFN showed enhanced solubility, reduced antigenicity, reduced sensitivity to proteolysis, and reduced rate of kidney clearance. The development of PEG-IFN has significantly improved the eradication rates of HCV infection and, adherence to treatment. Two forms of PEG-IFN have been developed, based on two pegylated chemistries: the 12-kDa linear PEG-IFN $\alpha 2 b$ and the $40-k D a$ branchy PEG-IFN- $\alpha$ 2a. ${ }^{(36)}$ Mathematical models have been described to infer the mechanisms of action of IFN. When following the initial dose, there is a rapid viral decline, between 0.5 to $2.0 \mathrm{log}$, during the next 24 to 48 hours due free virion clearance. The degree of antiviral effectiveness in blocking viral production, following viral declines, is more slow over the next 14 days. In this stage, the viral decline is primarily dependent on the blocking of new virions. ${ }^{(37,21)}$ The standard therapy, for patients with HCV infection, is the administration of PEG-IFN $\alpha$ by period of 48 weeks in case of HCV genotypes 1, 4, 5, and 6 or 24 weeks for HCV genotypes 2 and 3. ${ }^{(38)}$

RIB: The RIB is an inhibitor of some viral RNA guanylyl transferase and guanine-7N-methyl transferase enzymes that may contribute to a defective 5'-cap structure of viral mRNA transcripts and inefficient viral translation for certain DNA viruses. It has been suggested that incorporation of RIB into the 5 '-end of mRNA transcripts would mimic the 7-methyl guanosine endcap of cellular mRNAs, causing poor cellular translation of these. This process could generate a cell-toxic effect, but it does not seem to be important at therapeutic RIB concentrations. Any difference between cellular and viral enzyme handling of RIB-containing mRNA transcripts is a potential mechanism of differential inhibition of RIB to translation of mRNAs from viruses. ${ }^{(39)}$. RIB is also incorporated into the viral genome causing lethal mutagenesis and a 
subsequent decrease in specific viral infectivity. (38) The most common and significant side effect of RIB therapy is hemolytic anemia. Hemoglobin concentrations reach a nadir after $4^{-8}$ weeks after the start of treatment. The prevalence is $19-29 \%$ with Peg-IFN $\alpha$ and RIB dual therapy and 37-49 $\%$ in triple therapy. ${ }^{(28,40)}$ This adverse effect of RIB is reversible, and hemoglobin concentrations will return to pretreatment concentrations after termination of therapy. ${ }^{(41)}$ Lindahl et al. ${ }^{(42)}$ found that RIB-induced hemolytic anemia was dependent on RIB plasma concentrations rather than on dose per kilogram body weight. Other factors apart from RIB concentrations can play a role in developing or worsening anemia, for example, the bone marrow suppressive effect of Peg-IFN and suboptimal endogenous erythropoietin production. RIBinduced anemia is treated by dose reduction and/or treatment with erythropoietin or blood transfusions. Another serious adverse effect of RIB is that the drug are demonstrated to have significant teratogenic effects in all animal species exposed to RIB. ${ }^{(43-45)}$ It is therefore contraindicated in pregnant women, and a negative pregnancy test is required before starting HCV therapy including RIB.

The standard therapy for patients with HCV infection has been the use of PEG-IFN $\alpha$ plus RIB. (38) After dual therapy with PEG-IFN $\alpha$ and RIB, treatment response varies according to $\mathrm{HCV}$ genotype. It ranges from 40-50\%, in patients with genotype 1 or 4 , and from $70-80 \%$, in genotype 2 or $3 .{ }^{(46-49)}$ When the DAAs, which will be mentioned later, boceprevir or telaprevir are added to PEGIFN $\alpha$ and RIB for genotype infections, these drugs increase SVR rates by $25-31 \% .{ }^{(28,40)}$

$D A A$ : The DAAs are assuming a more important role in HCV treatment. The DAAs are classified according to their action sites, such as a protease inhibitor, polymerase inhibitor, NS5B inhibitor, and $\mathrm{NS} 5 \mathrm{~A}$ inhibitor. The main mechanism of action is the inhibition of the enzyme, protease or polymerase. Another mechanism of action in HCV therapy is to target the host factors that the virus uses to its life cycle, such example, cyclophilin inhibitors or nitazoxanide. ${ }^{(50)}$ Two first-generation telaprevir and boceprevir were licensed for use in conjunction with PEG-IFN $\alpha$ and RIB in adult patients chronically infected with HCV genotype 1. Telaprevir is an HCV protease inhibitors approved in U.S., in Canada, in European Union, and Japan. Telaprevir is a peptidomimetic inhibitor of the HCV non-structural 3-4A serine protease, not only interrupting the viral life-cycle, but would also restore the innate immune response. ${ }^{\left({ }^{11}\right)}$ Boceprevir is another HCV protease inhibitors approved in the U.S. and Europe for treating chronic genotype $1 \mathrm{HCV}$ infection. Boceprevir is covalent linear inhibitors that act via formation of a reversible covalent interaction with serine-139, that if binds reversibly to the $\mathrm{NS}_{3}$ protease active site and shows potent activity in the HCV replicon system. ${ }^{(52)}$

Actually, hepatitis C therapy is undergoing a revolution. Enormous research and development efforts have produced a large number of new antiviral drugs, including DAA and host-targeted agents. In 2013, the US FDA approved two more drugs for HCV treatment: simeprevir for genotype 1 infections (in combination with PEG-IFN $\alpha$ and RIB); and sofosbuvir for patients with genotype 1 or 4 (with PEG-IFN $\alpha$ and RIB) and for patients with genotype 2 or 3 (with RIB). ${ }^{(53-55)}$ These two new targeted drugs have further improved SVR rates to $80-90 \%$. In addition, these new drugs are better tolerated, their treatment schedules are less complex and there are fewer drug-drug interactions. More than 90\% of infections were reported to be cured in phase II and III trials, with or without PEG-IFN $\alpha$ and/or RIB. However, a number of unresolved issues remain. PEG-IFN $\alpha$ will remain the backbone of some HCV treatment strategies in 2014 and 2015, before the slowly disappearing from HCV treatment regimens, at least in areas of the world that will be able to afford the high cost of IFN-free combinations. RIB can be used to increase rates of SVR or to shorten treatment duration without altering the rates of SVR with both PEG-IFN $\alpha$ and IFN-free regimens because it prevents relapses through unknown mechanisms. For this reason could remain a useful adjunct in some IFN-free treatment strategies. Researchers aim to improve the currently available classes of HCV drugs. Second- and third-generation 
NS3-4A protease inhibitors, nucleoside/nucleotide analogues, non-nucleoside inhibitors of HCV RNAdependent RNA polymerase, and NS5A inhibitors that have increased potency, pan-genotypic antiviral activity, and high barriers to resistance likely will enter clinical development within the next 2-5 years. It is unlikely that further investment will be made beyond this point because there will be a sufficient number and range of drugs to fulfill clinical needs. In 2014 and 2015, new IFN-containing and IFN-free regimens will become available. Starting in 2015 and onward, IFN-containing regimens will be replaced by all-oral, IFN-free therapies, at least in areas of the world where these regimens are approved, and their cost is covered. ${ }^{(56)}$

\section{MEASURES OF PREVENTION}

The pathways of transmission include bloodblood link, such as occur during IDU's, and sexual contact. An important question is co-infection with HIV that is very often. It has been estimated that $25 \%$ of people, infected with HIV, in the United States, are also infected with HCV. In South America, Brazil study, HCV/HIV co-infection rates vary from $4.4 \%$ to $36.2 \%$. (57) Blood safety has been changing since HIV outbreak in 1980's, and many parts of the world, the NAT became reliable way to decrease blood-borne infectious diseases. ${ }^{\left({ }^{8}\right)}$ The IDU's are considered to be the main risk group for HCV infection acting as a source of this infection because the use of injecting drugs correlates strongly with HCV infection in the entire world. IDU's infected at an early age become an important reservoir beyond the higher risk of HIV co-infection or other parenterally transmitted viruses, which make HCV more difficult to eliminate. ${ }^{(59)}$ Considering IDU, it is important to determine the route transmission and virus similarity. A study has showed the intra-familial transmission of HCV based on bioinformatics analyses. This work demonstrated that two relatives living in the same house were infected by less divergent strains than two subjects living in different houses or belonging to different families. ${ }^{(60)}$ Another group that's exposed to HCV infection risk is the Healthcare workers. In the last 30 years, the transmission among this group decreased strongly, despite still needed control measures. Laboratory workers are at risk of a variety of hazards doing their work, such as collection, transport, processing, and analysis of patient specimens that represent risk for contamination. ${ }^{(61)}$

The prevention of HCV transmission is a challenge to public health authorities because it is very complicated follow a single strategy to control this disease. For IDU's, for example, harm reduction programs have been tried in many countries with activities as condom distribution, serological screening, and disposable syringes exchange. ${ }^{(62)}$ Healthcare workers integrated approach to prevention should be adopted. Education and training, elimination of unnecessary needles, adopting safe procedures for using and disposing of sharps, use of personal protection devices, and following appropriate surveillance and monitoring, response and follow-up of accidentallyexposed workers., are all necessary elements to guarantee an appropriated working environment. .The development of an efficient vaccine to prevent $\mathrm{HCV}$ infection has been hampered because HCV is an RNA virus. In addition to the difficulty in raising protective immune responses in human beings using classic approaches, and also by the uncertain definition of the target populations.. These factors have caused many companies to withdraw from this field of investigation. The antiviral approach therefore probably will be the only option to control the HCV epidemic. This will be possible only by combining highly efficient and well-tolerated, affordable drug combinations, active screening strategies, and easy access to care. ${ }^{(63)}$

\section{REFERENCES}

1. de Oliveira Andrade LJ, D'Oliveira A, Melo RC, De Souza EC, Costa Silva CA, Paraná R. Association between hepatitis $C$ and hepatocellular carcinoma. J Glob Infect Dis. 2009;1:33-7 
2. Zhu YZ, Qian XJ, Zhao P, Qi ZT. How hepatitis C virus invades hepatocytes: The mystery of viral entry. World J Gastroenterol. 20147;20:3457-67.

3. Choo QL, Kuo G, Weiner AJ, Overby LR, Bradley DW, Houghton M. Isolation of a cDNA clone derived from a blood-borne non-A, non-B viral hepatitis genome. Science. 1989;244:359-62.

4. Saludes V, González V, Planas R, Matas L, Ausina $V$, Martró E. Tools for the diagnosis of hepatitis $C$ virus infection and hepatic fibrosis staging. World J Gastroenterol. 2014;20:343142.

5. González-Moreno J, Payeras-Cifre A. Hepatitis $C$ virus infection: looking for interferon free regimens. ScientificWorld Journal. 2013;2013:825375.

6. Giannini C, Bréchot C. Hepatitis $C$ virus biology. Cell Death Differ. 2003;10 Suppl 1:S27-38.

7. Gupta E, Bajpai M, Choudhary A. Hepatitis C virus: Screening, diagnosis, and interpretation of laboratory assays. Asian J Transfus Sci. 2014;8:19-25.

8. Ghany MG, Strader DB, Thomas DL, Seeff LB. American association for the study of liver diseases. Diagnosis, management, and treatment of hepatitis $\mathrm{C}$ : An update. Hepatology. 2009;49:1335-74.

9. Simmonds P, Bukh J, Combet C, Deléage G, Enomoto N, Feinstone S, et al. Consensus proposals for a unified system of nomenclature of hepatitis $C$ virus genotypes. Hepatology. 2005;42:962-73.

1O. Ramia S, Eid-Fares J. Distribution of hepatitis C virus genotypes in the Middle East. Int J Infect Dis. 2006;10:272-7.

11. Zein NN. Clinical significance of hepatitis C genotypes. Clin Microbiol Rev. 2000;13:223-35.

12. Pereira LM, Martelli CM, Moreira RC, MerchanHamman E, Stein AT, Cardoso MR, et al. Prevalence and risk factors of Hepatitis $C$ virus infection in Brazil, 2005 through 2009: a crosssectional study. BMC Infect Dis. 2013;13:60.

13. Silva LK, Silva MB, Lopes GB, Rodart IF, Costa FQ, Santana NP, et al. Prevalence of hepatitis $\mathrm{C}$ virus infection and $\mathrm{HCV}$ genotypes among hemophiliacs in the state of Bahia, Northeastern Brazil: analysis of serological and virological parameters. Rev Soc Bras Med Trop. 2005; 38:496-502.

14. Silva MB, Andrade TM, Silva LK, Rodart IF, Lopes GB, Carmo TM, et al. Prevalence and genotypes of hepatitis $C$ virus among injecting drug users from Salvador-BA, Brazil. Mem Inst Oswaldo Cruz. 2010;105:299-303.

15. Meredith LW, Wilson GK, Fletcher NF, McKeating JA. Hepatitis C virus entry: beyond receptors. Rev Med Virol. 2012;22:182-93.

16. Blanchard E, Belouzard S, Goueslain L, Wakita T, Dubuisson J, Wychowski C, et al. Hepatitis $C$ virus entry depends on clathrin-mediated endocytosis. J Virol. 2006;80:6964-72.

17. Kim CW, Chang KM. Hepatitis C virus: virology and life cycle. Clin Mol Hepatol. 2013;19:17-25.

18. Bartenschlager R, Penin F, Lohmann V, Andre P. Assembly of infectious hepatitis $C$ virus particles. Trends Microbiol. 2011;19:95-103.

19. Jiang J, Cun W, Wu X, Shi Q, Tang H, Luo G. Hepatitis $C$ virus attachment mediated by apolipoprotein $E$ binding to cell surface heparan sulfate. J Virol. 2012;86:7256-67.

2O. Targett-Adams P, Boulant S, Douglas MW, McLauchlan J. Lipid metabolism and HCV infection. Viruses. 2010;2:1195-217.

21. Neumann AU, Lam NP, Dahari H, Gretch DR, Wiley TE, Layden TJ, et al. Hepatitis C viral dynamics in vivo and the antiviral efficacy of interferon-alpha therapy. Science. 1998;282:1037.

22. Morishima C, Gretch DR. Clinical use of hepatitis $C$ virus tests for diagnosis and monitoring during therapy. Clin Liver Dis. 1999;3:717-40.

23. Colin C, Lanoir D, Touzet S, Meyoud-Kraemer L, Bailley F, Trepo C. et al. Sensitivity and specificity of third-generation hepatitis $C$ virus antibody detection assays: An analysis of the literature. J Viral Hepat. 2001;8:87-95.

24. Chevaliez S, Pawlotsky JM. Hepatitis C virus serologic and virologic tests and clinical diagnosis of HCV-related liver disease. Int J Med Sci. 2006;3:35-40.

25. Murphy DG, Willems B, Deschênes M, Hilzenrat N, Mousseau R, Sabbah S. Use of sequence 
analysis of the NS5B region for routine genotyping of hepatitis $C$ virus with reference to $C / E l$ and 5 ' untranslated region sequences. $J$ Clin Microbiol. 2007;45:1102-12.

26. González V, Gomes-Fernandes M, Bascuñana E, Casanovas S, Saludes V, Jordana-Lluch E, et al. Accuracy of a commercially available assay for $\mathrm{HCV}$ genotyping and subtyping in the clinical practice. J Clin Virol. 2013;58:249-53.

27. Kwo PY, Lawitz EJ, McCone J, Schiff ER, Vierling $J M$, Pound D, et al. Efficacy of boceprevir, an NS3 protease inhibitor, in combination with peginterferon alfa- $2 b$ and ribavirin in treatmentnaive patients with genotype 1 hepatitis $C$ infection (SPRINT-1): an open-label, randomised, multicentre phase 2 trial. Lancet. 2010;376:70516.

28. Poordad F, McCone J Jr, Bacon BR, Bruno S, Manns MP, Sulkowski MS, et al. Boceprevir for untreated chronic HCV genotype 1 infection. N Engl J Med. 2011;364:1195-2O6.

29. McHutchison JG, Everson GT, Gordon SC, Jacobson IM, Sulkowski M, Kauffman R, et al. Telaprevir with peginterferon and ribavirin for chronic HCV genotype 1 infection. N Engl J Med. 2009;360:1827-38.

3O. Fontaine H, Pol S. Antiviral activity of telaprevir and boceprevir for the treatment of hepatitis $C$ virus infection in treatment-experienced patients. Clin Res Hepatol Gastroenterol. 201;35:S59-63.

31. Chopra A, Klein PL, Drinnan T, Lee SS. How to optimize HCV therapy in genotype 1 patients: management of side-effects. Liver Int. 2013;33:30-4.

32. Sulkowski MS, Cooper C, Hunyady B, Jia J, Ogurtsov P, Peck-Radosavljevic M, et al. Management of adverse effects of Peg-IFN and ribavirin therapy for hepatitis C. Nat Rev Gastroenterol Hepatol. 201;8:212-23.

33. Kawaguchi Y, Mizuta T, Eguchi Y, Sakurai E, Motomura $\mathrm{Y}$, Isoda $\mathrm{H}$, et al. Whole-body insulin resistance is associated with elevated serum $\alpha$-fetoprotein levels in patients with chronic hepatitis C. Intern Med. 2013;52:2393-2400.

34. Khattab MA, Eslam M, Alavian SM. Hepatitis $C$ virus as a multifaceted disease: a simple and updated approach for extrahepatic manifestations of hepatitis $C$ virus infection. Hepat Mon. 2010;10:258-69.

35. Laver GM, Walker BD. Hepatitis $C$ virus infection. N Engl J Med 2001; 345:41-52.

36. Andrade LJ, Atta AM, D'Almeida Junior A, Paraná R. Thyroid dysfunction in hepatitis $C$ individuals treated with interferon-alpha and ribavirin--a review. Braz J Infect Dis. 2008;12:144-8.

37. Dixit NM, Layden-Almer JE, Layden TJ, Perelson AS. Modelling how ribavirin improves interferon response rates in hepatitis $\mathrm{C}$ virus infection. Nature. 2004;432:922-4.

38. Hadziyannis SJ, Sette H Jr, Morgan TR, Balan V, Diago M, Marcellin P, et al. Peginterferonalpha2a and ribavirin combination therapy in chronic hepatitis $\mathrm{C}$ : a randomized study of treatment duration and ribavirin dose. Ann Intern Med. 2004;140:346-55.

39. Sidwell RW, Huffman JH, Khare GP, Allen LB, Witkowski JT, Robins RK. Broad-spectrum antiviral activity of Virazole: 1-beta-Dribofuranosyl-1,2,4-triazole-3-carboxamide. Science. 1972;177:705-6.

4O. Jacobson IM, McHutchison JG, Dusheiko G, Di Bisceglie AM, Reddy KR, Bzowej NH, et al. Telaprevir for previously untreated chronic hepatitis $C$ virus infection. $N$ Engl J Med. 2011;364:2405-16.

41. Poynard T, Marcellin P, Lee SS, Niederau C, Minuk GS, Ideo G, et al. Randomised trial of interferon alpha2b plus ribavirin for 48 weeks or for 24 weeks versus interferon alpha $2 b$ plus placebo for 48 weeks for treatment of chronic infection with hepatitis $C$ virus. International Hepatitis Interventional Therapy Group (IHIT). Lancet. 1998;352:1426-32.

42. Lindahl K, Schvarcz R, Bruchfeld A, Stahle L. Evidence that plasma concentration rather than dose per kilogram body weight predicts ribavirin-induced anaemia. J Viral Hepat. 2004;11:84-7.

43. FDA. Copegus prescribing information. Available from: http://www.accessdata.fda.gov/ drugsatfda_docs/label/2O13/O21511sO26lbl.pdf. Accessed 11 July 2014. 
44. Rebetol product information. 2013. Available from: http://www.ema.europa.eu/docs/en_GB/ document_library/EPAR_-_Product_Information/ human/OOO246/WC500048210.pdf. Accessed 11 July 2014.

45. FDA. Rebetol prescribing information. 2013. Available from: http://www.accessdata.fda.gov/ drugsatfda_docs/label/2O13/O2O9O3sO52,O21 546sOO8lbl.pdf. Accessed 11 July 2014.

46. Fried MW, Shiffman ML, Reddy KR, Smith C, Marinos G, Gonçales FL Jr, et al. Peginterferon alfa-2a plus ribavirin for chronic hepatitis $\mathrm{C}$ virus infection. N Engl J Med. 2002;347:975-82.

47. Khuroo MS, Khuroo MS, Dahab ST. Metaanalysis: a randomized trial of peginterferon plus ribavirin for the initial treatment of chronic hepatitis $\mathrm{C}$ genotype 4 . Aliment Pharmacol Ther. 2004;2O:931-8.

48. Manns MP, McHutchison JG, Gordon SC, Rustgi VK, Shiffman M, Reindollar R, et al. Peginterferon alfa-2b plus ribavirin compared with interferon alfa-2b plus ribavirin for initial treatment of chronic hepatitis $\mathrm{C}$ : a randomised trial. Lancet. 2001;358:958-65.

49. Zeuzem S, Hultcrantz R, Bourliere M, Goeser T, Marcellin P, Sanchez-Tapias J, et al. Peginterferon alfa-2b plus ribavirin for treatment of chronic hepatitis $\mathrm{C}$ in previously untreated patients infected with $\mathrm{HCV}$ genotypes 2 or 3.J Hepatol. 2004;40:993-9.

50. Stedman CA. Current prospects for interferonfree treatment of hepatitis $\mathrm{C}$ in 2012. J Gastroenterol Hepatol. 2013;28:38-45.

51. L, Failla C, Santolini E, De Francesco R, La Monica N. NS3 is a serine protease required for processing of hepatitis $C$ virus polyprotein. $J$ Virol. 1993;67:4017-26.

52. Malcolm BA, Liu R, Lahser F, Agrawal S, Belanger B, Butkiewicz N, el al. SCH 503034, a mechanism-based inhibitor of hepatitis $C$ virus NS3 protease, suppresses polyprotein maturation and enhances the antiviral activity of alpha interferon in replicon cells. Antimicrob Agents Chemother. 2006;50:1013-20.

53. FDA. Olysio prescribing information. 2013. http://www. accessdata.fda.gov/drugsatfda_ docs/label/2O13/2O5123sOOllbl.pdf. Accessed 19 May 2014.
54. FDA. Sovaldi prescribing information. 2013. http://www. accessdata.fda.gov/drugsatfda_ docs/label/2O13/2O4671sOOOlbl.pdf. Accessed 19 May 2014.

55. EMA. Sovaldi; product information. 2014. http://www.ema.europa.eu/docs/en_GB/ document_library/EPAR_-_Product_Information/ human/OO2798/WC500160597.pdf. Accessed 19 May 2014.

56. Pawlotsky JM. New Hepatitis C Therapies: The Toolbox, Strategies, and Challenges. Gastroenterology. 2014;146:1176-92.

57. Zhou YB, Wang $Q X$, Liang S, Gong YH, Yang $M X, N i e S J$, et al. HIV-, HCV-, and Co-Infections and Associated Risk Factors aong Drug Users in Southwestern China: A TownshipLevel Ecological Study Incorporating Spatial Regression. PLoS One. 2014;9:e93157.

58. Távora LG, Hyppolito EB, Cruz JN, Portela NM, Pereira SM, Veras CM. Hepatitis B, C and HIV co-infections seroprevalence in a northeast Brazilian center. Arq Gastroenterol. 2013;50:277-80.

59. de Mendoza C, Altisent C, Aznar JA, Batlle J, Soriano V. Emerging viral infections-a potential threat for blood supply in the 21 st century. AIDS Rev. 2012;14:279-89.

6O. Silva MB, Andrade TM, Silva LK, Rodart IF, Lopes GB, Carmo TM, et al. Prevalence and genotypes of hepatitis $C$ virus among injecting drug users from Salvador-BA, Brazil. Mem Inst Oswaldo Cruz. 2010;105:299-303.

61. Abdelwahab SF, Hashem M, Galal I, Sobhy M, Abdel-Ghaffar TS, Galal G, et al. Incidence of hepatitis $C$ virus infection among Egyptian healthcare workers at high risk of infection. $J$ Clin Virol. 2013;57:24-8.

62. Féray C, Bouscaillou J, Falissard B, Mohamed MK, Arafa N, Bakr I, et al. A novel method to identify routes of hepatitis $C$ virus transmission. PLoS One. 2014;9:e86098.

63. Lamers MH, Broekman MM, Boucher CA, Brouwer JT, Burger DM, van Hoek B, et al. Treatment of hepatitis $C$ monoinfection in adults-Dutch national guidelines. Neth J Med. 2013;71:377-85. 